\title{
The Perception of Website Accessibility: A Survey of Turkish Software Professionals
}

Pinar ONAY DURDU, Kocaeli University, Department of Computer Engineering, Assistant Professor, pinar.onaydurdu@kocaeli.edu.tr, 0000-0002-0439-1702

Zehra ALTUNTAŞ, Kocaeli University, Department of Computer Engineering, MS, zehra.yerlikaya@kocaeli.edu.tr, 0000-0003-4337-1680

ABSTRACT

Websites become main information dissemination mechanism to a variety of audiences for a wide spectrum of organizations from commercial to governmental context. The universal design of this communication medium, which enables them to be accessible for all people, becomes an important issue. However, currently websites are still not accessible. One of the reason for this situation can be based on the lack of awareness and understanding of software professionals who develop them since they have the greatest influence.

In this study, the aim was to reveal the current situation among software professionals who contributed in any stage of the website development in Turkey by mainly focusing on their perceptions of website accessibility and related issues. A web-based questionnaire was implemented with 108 participants from academy, industry and government to reveal the perceptions regarding the relationship between accessibility, user experience (UX) and usability as well as professionals' perspectives on related issues such as the need of a standard accessibility definition, accessibility evaluation methods, and accessibility drivers. Data gathered from the questionnaire was mainly subjected to descriptive statistics and t-test was applied to reveal the effects of expertise level, background, work domain and specialization. The results showed that software professionals prefer inclusive definitions for website accessibility by relating it to all people. They agreed that accessibility, usability and UX are related concepts and user-centered practices should be applied to enable the website accessibility. In addition, they thought that legislations should be enabled to ensure web accessibility. Experienced professionals and professionals from governmental organizations supported these views more according to t-test results. Although the findings provide the snapshot of the Turkish situation regarding website accessibility perceptions, these perceptions are critical since they provide guidance on shared understanding for the accessibility community.

Keywords : Web accessibility, Usability, User Experience (UX), Software Professionals' Perceptions, Universal Design 


\section{Web Sitelerinde Erişilebilirlik Algısı: Türk Yazılım Uzmanları Üzerine Bir} Araştırma

Web siteleri, ticari alandan devlet kuruluşlarma kadar geniş bir yelpazede çeşitli kitlelere temel bilgi yayma mekanizması haline gelmiştir. Bu iletişim ortamının tüm insanlar için erişilebilir olmasın sağlayan evrensel tasarım önemli bir konu haline gelmektedir. Ancak, şu anda web sitelerinde halen erişilebilirlik problemleri mevcuttur. Bu durumun nedenlerinden biri, web sitelerini geliştiren ve üzerlerinde en büyük etkiye sahip oldukları düşünülen yazılım uzmanlarının farkındalık ve anlayış eksikliğine dayanabilir.

Bu çalışmada, Türkiye'deki web sitesi geliştirmenin herhangi bir aşamasında katkıda bulunan yazllım uzmanları arasindaki mevcut durumu, esas olarak web sitesi erişilebilirliği ve ilgili konulardaki algilarına odaklanarak ortaya koymak amaçlanmıştır. Erişilebilirlik, kullanıcı deneyimi ve kullanılabilirlik arasındaki ilişkinin yanı sıra uzmanların standart erişilebilirlik tanımı, erişilebilirlik değerlendirme yöntemleri ve erişilebilirlik faktörleri gibi ilgili konulara ilişkin bakış açıların ortaya çıkarmak için akademi, endüstri ve devlet kurumlarından 108 katılımcryla web tabanl bir anket uygulanmıştır. Anketten elde edilen veriler ağırlıkl olarak betimleyici istatistiklere tabi tutulmuş ve uzmanlı düzeyi, arka plan, çalışma alanı ve uzmanlı̆̆ın etkilerini ortaya çıkarmak için $t$ testi uygulanmıştır. Sonuçlar, yazılım profesyonellerinin web sitesi erişilebilirliği için kapsayıcı tanımları tüm insanlarla ilişkilendirerek tercih ettiklerini göstermiştir. Erişilebilirlik, kullanılabilirlik ve kullanıcı deneyimi kavramlarının birbirleriyle ilişkili kavramlar olduğunu ve web sitesi erişilebilirliğini sağlamak için kullanıı merkezli yaklaşımların uygulanması gerektiğini düşünmektedirler. Ayrıca, web erişilebilirliğini sağlamak için mevzuatlarm etkinleştirilmesi gerektiğini belirtmektedirler. Deneyimli profesyonellerin ve devlet kurumlarmdan profesyonellerin, t-test sonuçlarma göre bu görüşleri daha fazla destekledikleri görülmektedir. Her ne kadar bulgular, Türkiye'nin web sitesi erişilebilirlik algılar ile ilgili durumunun anlık bir görüntüsünü sunsa da, erişilebilirlik topluluğu için paylaşılan anlayış konusunda rehberlik sağladığı için de bu alğlar kritik önem taşımaktadır.

Anahtar Kelimeler
Web Erişilebilirliği, Kullanılabilirlik, Kullanıcı Deneyimi, Yazılım Uzmanlarının Algıları, Evrensel Tasarım 


\section{INTRODUCTION}

Nowadays websites become the main information dissemination mechanism to the public for many institutions. People also use it to perform many of their daily operations such as finance, social networking or entertainment. Websites in any domain have various target user groups and providing accessible information and services to all these groups become essential. Disabled people are the ones often overlooked among the various groups despite the fact that about $15 \%$ of world's population is estimated to having a disability(WHO, 2019). In Turkey, the number of disabled people is estimated to be five million which is about $6.9 \%$ of the population (TurkStat, 2011, 2019). In addition, the age of population is getting older, which causes increase in the number of disabled people since people have vision defects or loose some other capabilities by aging. Thus, website accessibility has become a relevant topic that aim to develop inclusive websites that will be accessible to all people without defining any target group (“KAMİS Erişilebilirlik Nedir?,” 2019; Laux, 1998).

As the web becomes indispensable for the many aspects of the daily life of all people, many countries require accessibility by laws and regulation, such as ISO 9241-20 (2008) or Section 508 (Section 508, 2018). In addition general guidelines were published by World Wide Web Consortium (W3C) in Web Content Accessibility Guideline (WCAG) 1.0 (W3C, 1999) or 2.0 (W3C, 2008). Currently Turkey does not have any law or legislation specific to web accessibility. However, Turkey has signed United Nations' Convention on the Right of Person with Disabilities in 2009 (TTB, 2009) and accepted to ensure the accessibility issues for all people with this convention. Recently, The Ministry of Family and Social Policies (2019) has adopted WCAG guidelines and declared to ensure accessibility of public websites although there is still no legal requirement.

Website accessibility has been concerned by academia since mid 90's and various studies have been conducted. These studies generally focused on the accessibility evaluation of websites by using automated tools (Cojocar \& Guran, 2013; Ismail \& Kuppusamy, 2018; Zaphiris \& Ellis, 2001) that check the compliance of websites with WAI's WCAG 1.0 or WCAG 2.0 or by applying some manual evaluation methods such as heuristic evaluations 
(Paddison \& Englefield, 2004), user tests (Menzi-Çetin et al., 2017) or mixed methods (Aizpurua et al., 2016; Kurt, 2017; Lazar et al., 2004; Thompson et al., 2003). All these studies provide insight about the common accessibility problems and suggest some solutions. Despite all these studies and some legislative or regulatory initiatives for ensuring website accessibility, the websites are still inaccessible (Lazar et al., 2004). Therefore, recently, researchers started to focus on the reasons for not getting accessibility. They begin to investigate the views or awareness of people who took part in the development of websites such as programmers, developers, and webmasters since they have the greatest influence on websites (Inal et al., 2019; Lazar et al., 2004; Yesilada et al., 2015, 2012).

In this study, the aim was to reveal the current situation among software professionals who contributed in any stage of the website development in Turkey by mainly focusing on their perceptions of website accessibility and related issues. This study distinguishes itself from previous studies with its perception focus which tries to reveal the perceptions regarding the relationship between accessibility, user experience (UX) and usability as well as professionals' perspectives on related issues such as the need of a standard accessibility definition, accessibility evaluation methods, and accessibility drivers. A web-based questionnaire was implemented with participants from academy, industry and government. The result of the study is expected to contribute to the understanding of the accessibility issues in software development and to provide suggestions for future practices that would improve the situation by demonstrating the current perception of Turkish software professionals on website accessibility. These perceptions are critical since they provide shared understanding for the accessibility community.

\section{BACKGROUND}

\section{Definitions of accessibility, usability and user experience}

Web Accessibility Initiative (WAI) defines web accessibility as being perceivable, understandable and easily used by people with disabilities (W3C_WAI, 2019). However, there are many other definitions that extend the target of accessibility to older people (Thatcher et al., 2006) or to all users (Arch, 2009). Some others extend the definition to different context of use such as mobile (Yesilada et al., 2013). In addition, some definitions 
also consider accessibility as usability (ISO, 2008) or at least a part of usability (Arch, 2009). Thus there is not a commonly agreed upon only definition for web accessibility.

On the other hand, usability is considered as one of the most important quality attributes (Insfran \& Fernandez, 2008; Offutt, 2002) and a prerequisite for websites (Nielsen, 1999). Nielsen (Nielsen, 1994) explains the concept of usability with five attributes as learnability, effectiveness, ease in remembering, few mistakes and satisfaction. It is also defined as effectiveness, efficiency and satisfaction in the scope of specified users, specified goals and specified context of use in ISO 9241-11 (ISO, 2019). In addition user experience is a broader concept. It is defined as the users' perceptions and responses with regards to their interaction with a system or product (ISO, 2019). According to Hassenzahl (2003), user experience goes beyond task execution in an application and focuses on hedonic aspects of use such as fun and pleasure.

The concepts of usability and accessibility are geneuser really considered as inter-related in the scope of universal design (Henry, 2007). However, there are various views about the relationship between them. Some consider them as two discrete sets in which users with disabilities and others have different types of problems (Petrie \& Kheir, 2007) while some others consider that accessibility is a subset of usability problems (Thatcher et al., 2006). In addition, some suggests that both concepts can be considered under the topic of universal usability by including the problems of disabled people (Shneiderman, 2000). Yesilada, et al. (Yesilada et al., 2013) also support to extend the definition of accessibility to all people with or without disability including older people, regarding technology, environment and context of use such as mobile.

There are many definitions of accessibility as can be seen above. Therefore, revealing the perceptions of accessibility among software development professionals is essential since they have the main influence on ensuring accessibility. This will provide common understanding and form consensus on accessibility in accessibility community. 


\section{Related studies}

The investigation of the awareness and perception of accessibility among various software related professionals such as web developers, accessibility or UX experts was conducted by several studies since mid-2000s as can be seen in Table 1. All these studies were conducted to reveal issues such as the implementation of accessibility rate among professionals and their understanding about its definition, their awareness about accessibility standards and tools, the challenges they faced in ensuring accessibility, and their motivations for accessibility. The first reported study was Lazar et al.'s (Lazar et al., 2004) study which was conducted with 175 web masters from various countries. Accessibility implementation rate among web developers was about $65.7 \%$ and this was one of the most optimistic reported rate. The latter studies reported implementation rates, which were about $50 \%$ of less. Some of these studies were conducted with general software professionals (Antonelli et al., 2018; Cao \& Loiacono, 2018; Enabled Group, 2005; Lopes et al., 2010; Rosson et al., 2005; Tangarife \& Mont'alvao, 2006; Vollenwyder et al., 2019) while some included more specific domain of participants such as accessibility, HCI or UX specialists (Inal et al., 2019; Putnam et al., 2012; Yesilada et al., 2015, 2012). Many of them also included participants from various countries (Enabled Group, 2005; Lazar et al., 2004; Lopes et al., 2010; Yesilada et al., 2012) or some others focused on one country such as Brazil (Antonelli et al., 2018; Freire et al., 2008; Inal et al., 2019; Tangarife \& Mont'alvao, 2006), Switzerland (Vollenwyder et al., 2019) and Turkey (Inal et al., 2019).

Table 1. Previous studies on accessibility awareness of software professionals

\begin{tabular}{lcccc}
\hline \multicolumn{1}{c}{ Study } & $\begin{array}{c}\text { Number of } \\
\text { Participants }\end{array}$ & Country of origin & Roles & $\begin{array}{c}\text { Amount of awareness/ } \\
\text { amount of care given on } \\
\text { accessibility }\end{array}$ \\
\hline (Lazar et al., 2004) & 175 & $\begin{array}{c}\text { Various countries } \\
\text { mostly US } \\
\text { Various countries } \\
\text { mostly North } \\
\text { American }\end{array}$ & sw professionals & $65.7 \%$ \\
(Enabled Group, 2005) & 269 & NR & web developers & $36 \%$ \\
(Rosson et al., 2005) & 300 & Brazil & developers & $5 \%$ \\
(Tangarife \& Mont'alvao, 2006) & 68 & Brazil & organizations & $5.89 \%$ \\
(Ferreira et al., 2007) & 87 & Brazil & web developers & $53 \%$ \\
(Freire et al., 2008) & 613 & IBM & web developers & $19.9 \%$ \\
(Trewin et al., 2010) & 49 & & $75.5 \%$
\end{tabular}




\begin{tabular}{|c|c|c|c|c|}
\hline (Lopes et al., 2010) & 408 & $\begin{array}{l}\text { Various countries } \\
\text { mostly European }\end{array}$ & sw professionals & $50 \%$ \\
\hline (Yesilada et al., 2012) & 300 & Various countries & $\begin{array}{c}\text { mostly } \\
\text { accessibility/HCI } \\
\text { specialists }\end{array}$ & NR \\
\hline (Putnam et al., 2012) & 199 & NRs & $\begin{array}{l}\text { UX and HCI } \\
\text { professionals }\end{array}$ & $70 \%$ \\
\hline (Yesilada et al., 2015) & 300 & Various countries & $\begin{array}{c}\text { mostly } \\
\text { accessibility/HCI } \\
\text { specialists }\end{array}$ & NR \\
\hline (Inal et al., 2019) & 113 & Turkey & UX professionals & $31 \%$ \\
\hline (Antonelli et al., 2018) & 404 & Brazil & Web developers & $48.3 \%$ \\
\hline $\begin{array}{l}\text { (Yerlikaya \& Onay Durdu, } \\
\text { 2018) }\end{array}$ & 108 & Turkey & sw professionals & $48 \%$ \\
\hline (Cao \& Loiacono, 2018) & 76 & NR & $\begin{array}{l}\text { Student website and } \\
\text { app developers }\end{array}$ & NR \\
\hline (Vollenwyder et al., 2019) & 342 & Switzerland & Web developers & NR \\
\hline
\end{tabular}

Most of the above-mentioned studies were to reveal website accessibility awareness rates or whether accessibility practices are implemented or not. On the other, in Yesilada et al. implemented a questionnaire and reported the perceptions of accessibility and HCI specialists from various countries (Yesilada et al., 2015). They focused on the perception of participants on the relationship between accessibility, user experience (UX) and usability; inclusion and exclusion; and accessibility evaluation approaches to provide a common understanding of web accessibility. Findings revealed that accessibility and usability was considered as highly related and accessibility included everyone not just the disabled people. Participants reported accessibility evaluation should be based on user-centered practices in addition to conducting source code inspections with automated tools.

There were few studies considering professionals from Turkey. In the first one (Inal et al., 2019), 113 Turkish UX professionals' awareness, understanding and practices were investigated and $31 \%$ of implementation rate was reported. Yerlikaya and Onay Durdu also reported awareness rates of software professionals website accessibility as $48 \%$ (Yerlikaya \& Onay Durdu, 2018). Although both studies had overlapping points, the latter study's scope was different in that since it focused on the views of software professionals from all levels of website development effort. 


\section{METHOD}

In this study, the aim was to reveal the status regarding the perceptions of software developers about the website accessibility and related issues. The research was conducted as a descriptive study based on the questionnaire. The purpose of the descriptive investigation is to determine the general view of the sample or how often some events occur rather than revealing the relationship between variables (Oppenheim, 2000).

In that scope, Yesilada et al.'s $(2015,2012)$ studies were adopted and following research question and its sub-questions were tried to be answered;

- What are the perceptions of Turkish software professionals about website accessibility with respect to the related issues?

a. What is the common agreed upon definition for web accessibility among Turkish software professionals?

b. What do they think about the relationship between web accessibility and usability?

c. What do they think about whether web accessibility is for all or only for disabled people?

d. What do they think about web accessibility evaluation?

e. What do they think about the drivers that enable the implementation of web accessibility?

f. What do they think about the relationship between web accessibility and UX?

g. Are some factors such as expertise, technical background, specialization area or work domain effects their views on these issues?

\section{Participants}

There were 108 participants who had various roles in software development process in their organizations in the study. Table 2 summarizes their demographics. Of the respondents, 73 $(67.6 \%)$ were male and $35(32.4 \%)$ were female. The mean age of the participants was 32.43 . When the education levels of the participants were analyzed; 63 (58.3\%) of them had an undergraduate degree while $45(41.7 \%)$ of them had graduate degree. A large part of the 
participants $(\mathrm{N}=73,67.6 \%)$ was an engineering graduate (either computer engineering or other engineering). 18 people (16.7\%) were graduated from design / arts and 17 (15.7\%) from social sciences including humanities discipline. When the work domains of the participants' organizations were analyzed, it was observed that most participants worked in sectors such as research $(\mathrm{N}=29,26.9 \%)$, publishing $(\mathrm{N}=22,20.4 \%)$, education $(\mathrm{N}=20,18.5 \%)$ and telecommunication ( $\mathrm{N}=14,13 \%)$. Many of the participants worked as software engineer $(\mathrm{N}=42,38.9 \%)$ while the rest worked in various roles such as Project Manager / team leader $(\mathrm{N}=13,12 \%)$, web designer $(\mathrm{N}=9,8.3 \%)$ and owner / manager $(\mathrm{N}=8,7.4 \%)$.

The participants were grouped according to their expertise level, technical background, specialization area, work sector as these can affect the views of the participants (Yesilada et al., 2015) based on the several questions in the demographics part of the questionnaire. Expertise level was defined based on the answers of the questions dealing whether participants were implementing accessibility evaluation in their organizations such as whether they either knew or implemented accessibility evaluation tools in their projects, whether they enabled their websites for disabled people or whether they conducted any accessibility evaluation with disabled people while developing websites. If the participant answered positive at least 2 or more of these questions, they were considered as expert while if they answered only one of them or none of them positive then they were considered as non-expert. As a result, more than half of the participants were considered as expert (E) $(\mathrm{N}=62,57.4 \%)$ while the rest was considered non-expert (NE) $(\mathrm{N}=46,42.6 \%)$ based on this criteria. In order to define participants' technical background, respondents from fields of computer engineering and design/art who had a designer role were considered as technical (T) $(\mathrm{N}=73,67.6)$ and the rest of the fields were considered as non-technical $(\mathrm{NT})(\mathrm{N}=35,32.4)$. Work domain of the participants was divided into two groups as governmental $(G)$ and private $(\mathrm{P})$ based on their declared work sector. Research and education work sectors were classified as governmental ( $\mathrm{N}=71,65.7 \%)$, and the other sectors such as publishing, telecommunication, finance and e-commerce were classified as private ( $\mathrm{N}=37,34.3 \%)$. Finally, respondents' current specializations were categorized as user-oriented (Uo) $(\mathrm{N}=60$, $55.6 \%)$ and non-user oriented (NUo) $(\mathrm{N}=48,44.4 \%)$ based on whether these roles dealt with 
users' needs. The roles of software engineer, web designer, business analyst and web developers were categorized as user-oriented specializations while the rest including project manager, owner, system administrator tester or consultant were categorized into non-user oriented group.

Table 2. Demographics of participants

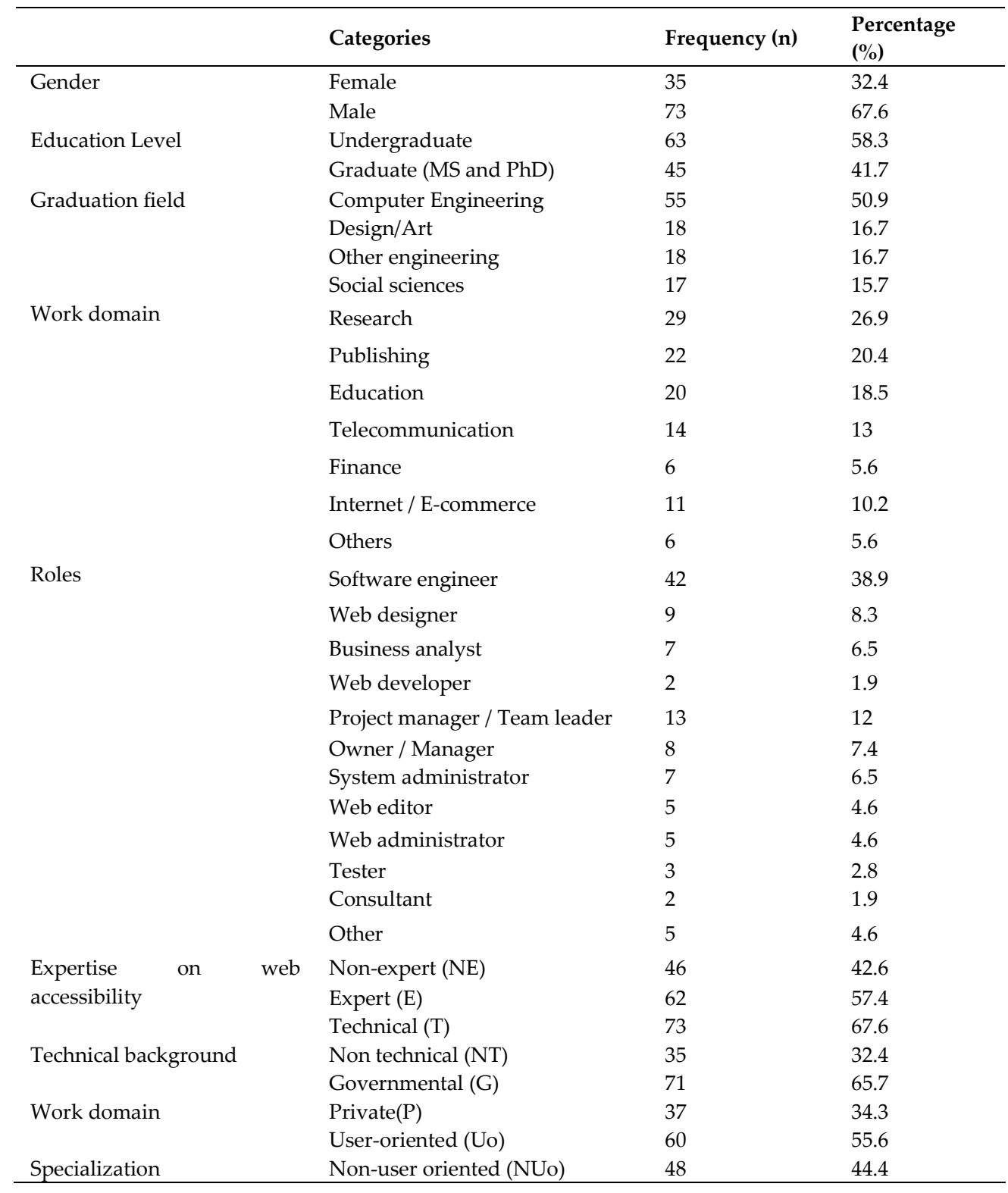

\section{Data Collection Tool}

A web-based questionnaire was prepared to gather data from software professionals in relation with the research questions. Ethics committee approval was gathered from Kocaeli 
University Ethics Committee of Science and Engineering Sciences for the questionnaire and the study. At the beginning of the questionnaire informed consent part was included that detailed the aim of the study as well as there is no explicit or implicit coercion for the participation. The questionnaire was composed of three sections. First part included questions regarding demographic information of the participants. They were about their gender, age, education level, graduation field, their organization's work domain, their role at their organization and their expertise in accessibility. Second part consisted of a question regarding the given definitions from the literature regarding the first sub-question of the research question. Third part consisted of web accessibility statements, which were formed as five-point Likert-type rating scale, regarding the sub-questions of the main research question. These were to investigate the participants' understanding of the definition of website accessibility in relation with the concepts of usability and UX. There were 34 questions regarding the participants' perceptions which were adopted from Yeşilada et al.'s (Yesilada et al., 2015) study. All questions were translated into Turkish and they were checked by two subject-matter experts who had a phD and were studying in Human Computer Interaction field and one language expert and updated in line with their feedback. Thus, face and content validity of the study was ensured (Black \& Champion, 1976). Questionnaire can be accessed online*

\section{Data Collection Procedure}

The questionnaire was prepared online by using Google Forms. The participants were invited by e-mail through e-mail lists related with website development, personal contacts and LinkedIn profiles. Participants' informed consent was gathered before filling the questionnaire. There were 108 software professionals who accessed and filled in the questionnaire from academia, industry and government organizations. The questionnaire was accessible to participants for three months. Since it was not possible to gather data by random sampling, using a self-selected, non-probabilistic approach, diverse sampling was used to gather various perceptions from software professionals from all levels of website development. 


\section{Data Analysis}

Data gathered from the questionnaire was mainly subjected to descriptive statistics. The goal of that analysis was to determine how much of the sample was having a particular idea, or how often something was happening (Oppenheim, 2000). For the data analysis, participants' "strongly agree" and "agree" ratings were merged together as "agree" while their "strongly disagree" and "disagree" ratings were merged as "disagree". In addition, inferential statistics were applied to see if factors such as participants' accessibility expertise level, background, specialization and work domain affects their perceptions of accessibility related issues. The data was also subjected to missing values analysis which revealed that $13.6 \%$ of the data were missing. Performing complete cases analysis would yield a loss of 40 (37\%) participants, as these participants had missing values on one or more items. According to Little's (1988) test of Missing Completely at Random (MCAR) was not significant, $\chi 2533.121, \mathrm{DF}=556, \mathrm{p}=.75$. When significant, this test suggests that the hypothesis that the data are MCAR can be rejected. Therefore, there was no evidence to suggest that the data were not MCAR. As such, pairwise deletion was used in the statistical analyses.

\section{RESULTS}

\section{Software professionals' web accessibility definition}

A question was asked to participants to gather their view of the definition for web accessibility. Five different accessibility definitions from the literature were presented. Participants were asked to order these definitions according to which they thought explained the concept best. Table 3 shows that each of the given definitions was chosen as the best choice in close proportions (15\% to $23 \%$ ). In addition, more participants preferred the definitions, which were more inclusive as their first choice (D1, D2 and D3).

Table 3. Ranking of web accessibility definitions ranking being a best definition (1st choice) to worst definition (5th choice)

\begin{tabular}{lllllllllllll}
\hline & & 1. Choice & 2. Choice & 3. Choice & & 4. Choice & 5. Choice \\
\hline D\# Definition & n & $\%$ & n & $\%$ & n & $\%$ & & n & $\%$ & n & $\%$ & $\%$ \\
\hline
\end{tabular}




\begin{tabular}{|c|c|c|c|c|c|c|c|c|c|c|c|}
\hline D1 & $\begin{array}{l}\text { Technology is accessible if it can be used as } \\
\text { effectively by people with disabilities as by those } \\
\text { without (Section } 508,2018 \text { ) }\end{array}$ & 25 & 23.4 & 13 & 12.1 & 22 & 20.6 & 37 & 34.6 & 10 & 9.3 \\
\hline D2 & $\begin{array}{l}\text { Web accessibility means that people with } \\
\text { disabilities can use the Web. More specifically, } \\
\text { Web accessibility means that people with } \\
\text { disabilities can perceive, understand, navigate and } \\
\text { interact with the Web, and that they can contribute } \\
\text { to the Web(WAI, 2018) }\end{array}$ & 20 & 18.7 & 12 & 11.2 & 44 & 41.1 & 24 & 22.4 & 7 & 6.5 \\
\hline D3 & $\begin{array}{l}\text { A website is accessible if it is effective, efficient } \\
\text { and satisfactory for more people in more } \\
\text { situations (Waddell et al., 2003) }\end{array}$ & 17 & 15.9 & 14 & 13.1 & 30 & 28 & 34 & 31.8 & 12 & 11.2 \\
\hline D4 & $\begin{array}{l}\text { The removal of all technical barriers to effective } \\
\text { interaction (Yesilada et al., 2012) }\end{array}$ & 18 & 16.8 & 12 & 11.2 & 21 & 19.6 & 47 & 43.9 & 9 & 8.4 \\
\hline D5 & $\begin{array}{l}\text { The extent to which a product website can be used } \\
\text { by specified users with specified disabilities to } \\
\text { achieve specified goals with effectiveness, } \\
\text { efficiency and satisfaction in a specified context of } \\
\text { use(ISO, 2008) }\end{array}$ & 16 & 14.8 & 14 & 13.1 & 33 & 30.6 & 35 & 32.4 & 10 & 9.3 \\
\hline
\end{tabular}

\section{Software professionals' web accessibility perceptions}

Questionnaire included web accessibility statements regarding the software professionals perceptions in alignment with the sub-questions of the research questions. These statements were grouped into seven subsets to provide information about the professionals' views on the relationship of website accessibility and usability (AU), scope of accessibility (disabled vs all - DA), motivational factors that drives the implementation of accessibility evaluation (accessibility drivers - AD), assessment methods (accessibility evaluation - AE), whether page structure or context have an effect (dynamic and contextual - DC) on accessibility, the standard definition (SD) and the relationship of website accessibility and UX (AUX). This section reports the findings regarding these statements.

\section{Perceptions of the relationship of website accessibility and usability}


Table 4 summarizes the first group of statements regarding the perceptions of software professionals about the relationship between website accessibility and usability. Many respondents $(\mathrm{N}=65,67.7 \%)$ expressed strong disagreement or disagreement that accessibility and usability were not related (S1_AU). Majority of them (N=78, $81.3 \%)$ also had similar disagreement on that usability problems only affected non-disabled people (S2_AU). About $66.3 \%$ of the respondents had an agreement with the statements S4_AU and S6_AU while around $52.2 \%$ of the respondents had an agreement with the statements of S5_AU and S7_AU. This showed that they thought that accessibility had more effect on usability than vice versa.

Table 4 . Statements regarding the relationship of website accessibility vs. usability

\begin{tabular}{|c|c|c|c|c|c|c|c|c|c|c|c|c|}
\hline \multirow[t]{2}{*}{$\#$} & \multirow[t]{2}{*}{ Statements } & \multirow[t]{2}{*}{$\mathbf{N}$} & \multirow[t]{2}{*}{$\mathbf{M}$} & \multirow[t]{2}{*}{ sd } & \multicolumn{2}{|c|}{ Disagree } & \multicolumn{2}{|c|}{ Neutral } & \multicolumn{2}{|c|}{ Agree } & \multicolumn{2}{|c|}{ NA } \\
\hline & & & & & $\mathbf{n}$ & $\%$ & $\mathbf{n}$ & $\%$ & $\mathbf{n}$ & $\%$ & $\mathbf{n}$ & $\%$ \\
\hline S1_AU & $\begin{array}{l}\text { Web accessibility and usability } \\
\text { problems are not related }\end{array}$ & 96 & 2.06 & 1.22 & 65 & 67.7 & 14 & 14.6 & 17 & 17.7 & - & - \\
\hline S2_AU & $\begin{array}{l}\text { Usability problems only affect } \\
\text { non-disabled people }\end{array}$ & 96 & 1.71 & 1.06 & 78 & 81.3 & 9 & 9.4 & 8 & 8.3 & 1 & 1.0 \\
\hline S3_AU & $\begin{array}{l}\text { Web accessibility problems are } \\
\text { a subset of usability problems }\end{array}$ & 92 & 3.43 & 1.05 & 11 & 12 & 32 & 34.8 & 47 & 51.1 & 2 & 2.2 \\
\hline S4_AU & $\begin{array}{l}\text { Accessible sites are more usable } \\
\text { for all }\end{array}$ & 92 & 3.55 & 1.38 & 7 & 7.6 & 17 & 18.5 & 61 & 66.3 & 7 & 7.6 \\
\hline S5_AU & $\begin{array}{l}\text { Usable sites are more accessible } \\
\text { for all }\end{array}$ & 92 & 3.35 & 1.21 & 18 & 19.6 & 24 & 26.1 & 48 & 52.2 & 2 & 2.2 \\
\hline S6_AU & $\begin{array}{l}\text { Accessible sites are more usable } \\
\text { for disabled people }\end{array}$ & 93 & 3.68 & 1.15 & 8 & 8.6 & 21 & 22.6 & 61 & 65.6 & 3 & 3.2 \\
\hline S7_AU & $\begin{array}{l}\text { Usable sites are more accessible } \\
\text { for disabled people }\end{array}$ & 90 & 3.38 & 1.31 & 20 & 22.2 & 20 & 22.2 & 47 & 52.2 & 3 & 3.3 \\
\hline
\end{tabular}

Note: Percentages are based on valid percent (i.e., missing values are not included).

\section{Perceptions of the scope of website accessibility}

The statements regarding the scope of website accessibility mainly dealt with what type of people are mostly affected by website accessibility. Nearly half of the participants $(N=45,49.5$ 
$\%)$ expressed strong disagreement or disagreement that web accessibility problems only affected disabled people (S8_DA) as seen in Table 5. Many of them (N=64, 70.3 \%) had also strong agreement that web accessibility problems affected all types of people (S9_DA). More respondents moderately agreed with statements S10_DA, S11_DA and S12_DA while there was neutrality regarding the statement S13_DA. Equal number of respondents either strongly agreed or strongly disagreed to that statement. These results were in accordance with the results gathered regarding the definition of website accessibility preferences of software professionals reported in section 3.2.

Table 5. Statements regarding the type of people who are mostly affected by accessibility

\begin{tabular}{|c|c|c|c|c|c|c|c|c|c|c|c|c|}
\hline \multirow[t]{2}{*}{ \# } & \multirow[t]{2}{*}{ Statements } & \multirow[t]{2}{*}{$\mathbf{N}$} & \multirow[t]{2}{*}{$\mathbf{M}$} & \multirow[t]{2}{*}{ sd } & \multicolumn{2}{|c|}{ Disagree } & \multicolumn{2}{|c|}{ Neutral } & \multicolumn{2}{|c|}{ Agree } & \multicolumn{2}{|c|}{ NA } \\
\hline & & & & & 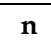 & $\%$ & $\mathbf{n}$ & $\%$ & $\mathbf{n}$ & $\%$ & n & $\%$ \\
\hline S8_DA & $\begin{array}{l}\text { Web accessibility problems } \\
\text { only affect disabled people }\end{array}$ & 91 & 2.66 & 1.34 & 45 & 49.5 & 10 & 11 & 34 & 37.4 & 2 & 2.2 \\
\hline S9_DA & $\begin{array}{l}\text { Web accessibility problems } \\
\text { affect all types of people } \\
\text { regardless of their situational } \\
\text { or physical limitations }\end{array}$ & 91 & 3.64 & 1.54 & 6 & 6.6 & 11 & 12.1 & 64 & 70.3 & 10 & 11 \\
\hline S10_DA & $\begin{array}{l}\text { Web accessibility benefits } \\
\text { mainly blind users }\end{array}$ & 90 & 3.24 & 1.31 & 24 & 26.7 & 13 & 14.4 & 49 & 54.4 & 4 & 4.4 \\
\hline S11_DA & $\begin{array}{l}\text { Web accessibility benefits } \\
\text { older users }\end{array}$ & 91 & 3.40 & 1.46 & 13 & 14.3 & 16 & 17.6 & 55 & 60.4 & 7 & 7.7 \\
\hline S12_DA & $\begin{array}{l}\text { Web accessibility is about } \\
\text { inclusion }\end{array}$ & 88 & 3.30 & 1.22 & 20 & 22.7 & 20 & 22.7 & 45 & 51.1 & 3 & 3.4 \\
\hline S13_DA & $\begin{array}{l}\text { Web accessibility is about } \\
\text { people with low income from } \\
\text { developing regions and } \\
\text { illiterate people }\end{array}$ & 88 & 2.84 & 1.32 & 32 & 36.4 & 22 & 25 & 32 & 36.4 & 2 & 2.3 \\
\hline
\end{tabular}

Note: Percentages are based on valid percent (i.e., missing values are not included).

Perceptions of motivational factors regarding website accessibility 
There were two statements that examined the perceptions of software professionals on the drivers that cause motivation for ensuring website accessibility. One of them stressed that website accessibility was motivated by legislations (S14_AD) and the other was by business revenue (S15_AD). Respondents appeared to be undecided with the statements regarding these drivers. The mean values of both statements were very close to each other and to neutrality ( $M=2.93$ and $M=2.82)$. More respondents $(\mathrm{N}=36,41.9 \%)$ strongly agreed or agreed that legislation was the main motivation for ensuring web accessibility than the ones $(\mathrm{N}=30$, $34.5 \%)$ that believed it was related with the business value, as given in Table 6 .

Table 6. Statements regarding drivers of accessibility

\begin{tabular}{|c|c|c|c|c|c|c|c|c|c|c|c|c|}
\hline \multirow[t]{2}{*}{ \# } & \multirow[t]{2}{*}{ Statements } & \multirow[t]{2}{*}{$\mathbf{N}$} & \multirow[t]{2}{*}{$\mathbf{M}$} & \multirow[t]{2}{*}{ sd } & \multicolumn{2}{|c|}{ Disagree } & \multicolumn{2}{|c|}{ Neutral } & \multicolumn{2}{|c|}{ Agree } & \multicolumn{2}{|c|}{ NA } \\
\hline & & & & & $\mathbf{n}$ & $\%$ & $\mathbf{n}$ & $\%$ & n & $\%$ & n & $\%$ \\
\hline S14_AD & $\begin{array}{l}\text { Legislation is the main } \\
\text { motivation for ensuring web } \\
\text { accessibility }\end{array}$ & 86 & 2.93 & 1.34 & 29 & 33.7 & 18 & 20.9 & 36 & 41.9 & 3 & 3.5 \\
\hline S15_AD & $\begin{array}{l}\text { Web accessibility is best viewed } \\
\text { in terms of business revenue }\end{array}$ & 87 & 2.82 & 1.30 & 33 & 37.9 & 21 & 24.1 & 30 & 34.5 & 3 & 3.4 \\
\hline
\end{tabular}

Note: Percentages are based on valid percent (i.e., missing values are not included).

\section{Perceptions of accessibility evaluation methods}

There were statements regarding the methods to be used in accessibility evaluation. Many of the respondents $(\mathrm{N}=56,62.2 \%)$ agreed and strongly agreed that accessibility might be ensured based on user-centered design (S16_AE) and they (N=59, 66.3\%) also believed that web accessibility should be enabled by running user tests (S17_AE) rather than reliance on inspections conducted on the source code (S21_AE). In addition many of them ( $\mathrm{N}=58,66.7 \%)$ believed that user test were more reliable and valid evaluation methods (S18_AE). Similarly, respondents ( $\mathrm{N}=48,57.1 \%)$ agreed that accessibility is a personal experience (S20_AE). All these responses show that the respondents believed that accessibility was a user-related phenomenon.

On the other hand, their responses evenly divided on that web accessibility of a page could be assessed in less than five minutes (S22_AE) and accessibility was only related with 
disabled people (S23_AE) as can be seen in Table 7. The respondents ( $\mathrm{N}=44,52.4 \%)$ also believed that WCAG training was required (S24_AE) and they ( $\mathrm{N}=34,41.5 \%$ ) moderately agreed relying on WCAG for accessibility evaluation (S25_AE).

Table 7. Statements regarding the accessibility evaluation methods

\begin{tabular}{|c|c|c|c|c|c|c|c|c|c|c|c|c|}
\hline \multirow[t]{2}{*}{$\#$} & \multirow[t]{2}{*}{ Statements } & \multirow[t]{2}{*}{$\mathbf{N}$} & \multirow[t]{2}{*}{$\mathbf{M}$} & \multirow[t]{2}{*}{ sd } & \multicolumn{2}{|c|}{ Disagree } & \multicolumn{2}{|c|}{ Neutral } & \multicolumn{2}{|c|}{ Agree } & \multicolumn{2}{|c|}{ NA } \\
\hline & & & & & $\mathbf{n}$ & $\%$ & $\mathrm{n}$ & $\%$ & $\mathrm{n}$ & $\%$ & $\mathbf{n}$ & $\%$ \\
\hline S16_AE & $\begin{array}{l}\text { Designing for web } \\
\text { accessibility must be } \\
\text { grounded in user-centered } \\
\text { design }\end{array}$ & 90 & 3.59 & 1.29 & 8 & 8.9 & 21 & 23.3 & 56 & 62.2 & 5 & 5.6 \\
\hline S17_AE & $\begin{array}{l}\text { Web accessibility can only } \\
\text { be assessed by running user } \\
\text { tests }\end{array}$ & 89 & 3.71 & 1.28 & 10 & 11.2 & 16 & 18 & 59 & 66.3 & 4 & 3.7 \\
\hline S18_AE & $\begin{array}{l}\text { Compared to other } \\
\text { methods web accessibility } \\
\text { can be assessed more } \\
\text { reliably and validly by } \\
\text { running user tests }\end{array}$ & 87 & 3.57 & 1.30 & 7 & 8 & 16 & 18.4 & 58 & 66.7 & 6 & 6.9 \\
\hline S19_AE & $\begin{array}{l}\text { Web accessibility can be } \\
\text { quantified and thus } \\
\text { compared across similar } \\
\text { pages }\end{array}$ & 86 & 3.51 & 1.25 & 10 & 11.6 & 19 & 22.1 & 53 & 61.6 & 4 & 4.7 \\
\hline S20_AE & $\begin{array}{l}\text { Accessibility is personal } \\
\text { experience and accessibility } \\
\text { evaluation should take this } \\
\text { into account }\end{array}$ & 84 & 3.55 & 1.17 & 11 & 13.1 & 24 & 28.6 & 48 & 57.1 & 1 & 1.2 \\
\hline S21_AE & $\begin{array}{l}\text { Web accessibility can be } \\
\text { assessed by only inspecting } \\
\text { the underlying source code } \\
\text { of a page }\end{array}$ & 83 & 2.81 & 1.19 & 39 & 47 & 17 & 20.5 & 27 & 32.5 & 0 & 0 \\
\hline S22_AE & $\begin{array}{l}\text { Web accessibility of a page } \\
\text { can be well assessed in less } \\
\text { than five minutes }\end{array}$ & 83 & 3 & 1.11 & 18 & 21.7 & 36 & 43.4 & 27 & 32.5 & 2 & 2.4 \\
\hline
\end{tabular}




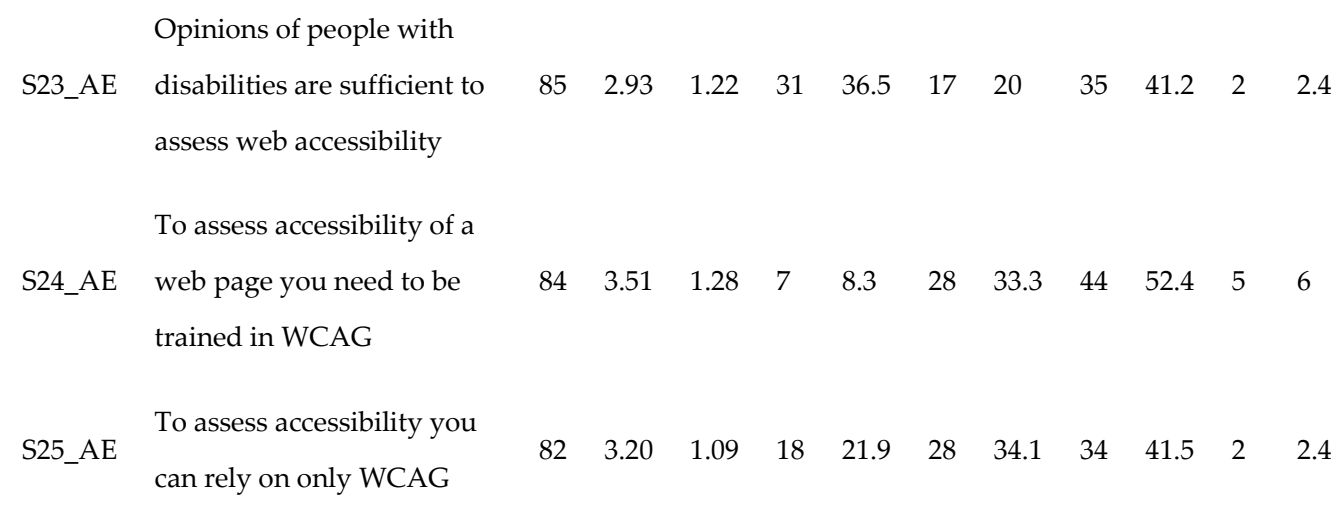

Note: Percentages are based on valid percent (i.e., missing values are not included).

\section{Perceptions regarding the effect of page structure on accessibility}

When the statements regarding with the effect of page structure on accessibility was analyzed, respondents moderately agreed on all the statements as in Table 8. Many of them agreed that web accessibility was affected by the dynamic pages (S26_DC), (N=47, $55.3 \%$ ) and page familiarity (S28_DC) $(\mathrm{N}=49,61.3 \%)$, and it was related with the context (S27_DC) ( $\mathrm{N}=45,54.2 \%$ ).

Table 8. Statements regarding the effect of page structure on accessibility

\begin{tabular}{|c|c|c|c|c|c|c|c|c|c|c|c|c|}
\hline \multirow[t]{2}{*}{ \# } & \multirow[t]{2}{*}{ Statements } & \multirow[t]{2}{*}{$\mathbf{N}$} & \multirow[t]{2}{*}{$\mathbf{M}$} & \multirow[t]{2}{*}{ sd } & \multicolumn{2}{|c|}{ Disagree } & \multicolumn{2}{|c|}{ Neutral } & \multicolumn{2}{|c|}{ Agree } & \multicolumn{2}{|c|}{ NA } \\
\hline & & & & & $\mathbf{n}$ & $\%$ & $\mathbf{n}$ & $\%$ & n & $\%$ & $\mathbf{n}$ & $\%$ \\
\hline S26_DC & $\begin{array}{l}\text { Web accessibility is highly } \\
\text { dynamic: it changes constantly } \\
\text { while interacting with a page }\end{array}$ & 85 & 3.42 & 1.25 & 11 & 12.9 & 23 & 27.1 & 47 & 55.3 & 4 & 4.7 \\
\hline S27_DC & $\begin{array}{l}\text { Web accessibility occurs in and is } \\
\text { dependent on the context in which } \\
\text { the web page is experienced }\end{array}$ & 83 & 3.46 & 1.08 & 6 & 7.2 & 29 & 34.9 & 45 & 54.2 & 3 & 3.6 \\
\hline S28_DC & $\begin{array}{l}\text { Prior exposure to a web page } \\
\text { shapes subsequent web } \\
\text { accessibility }\end{array}$ & 80 & 3.68 & 0.98 & 6 & 7.5 & 24 & 30 & 49 & 61.3 & 1 & 1.3 \\
\hline
\end{tabular}

Note: Percentages are based on valid percent (i.e., missing values are not included). 


\section{Perceptions regarding the need of a standard accessibility definition}

There was only one statement regarding the need for a standard definition for website accessibility. Respondents ( $\mathrm{N}=51,65.4 \%$ ) moderately agreed with the related statement (S29_SD) as can be seen in Table 9.

Table 9. Statements regarding the need of a standard accessibility definition

\begin{tabular}{|c|c|c|c|c|c|c|c|c|c|c|c|c|}
\hline \multirow[t]{2}{*}{$\#$} & \multirow[t]{2}{*}{ Statements } & \multirow[t]{2}{*}{$\mathbf{N}$} & \multirow[t]{2}{*}{$\mathbf{M}$} & \multirow[t]{2}{*}{ sd } & \multicolumn{2}{|c|}{ Disagree } & \multicolumn{2}{|c|}{ Neutral } & \multicolumn{2}{|c|}{ Agree } & \multicolumn{2}{|c|}{ NA } \\
\hline & & & & & $\mathbf{n}$ & $\%$ & $\mathbf{n}$ & $\%$ & n & $\%$ & $\mathbf{n}$ & $\%$ \\
\hline S29_SD & $\begin{array}{l}\text { There is a definite need for a } \\
\text { standardized definition of the } \\
\text { term 'web accessibility' }\end{array}$ & 78 & 3.63 & 1.21 & 10 & 12.8 & 14 & 17.9 & 51 & 65.4 & 3 & 3.8 \\
\hline
\end{tabular}

Note: Percentages are based on valid percent (i.e., missing values are not included).

\section{Perceptions regarding the relationship between website accessibility and UX}

Table 10 summarizes the responses regarding the relationship between accessibility and user experience. Respondents moderately disagreed that web accessibility and user experience were not related (S32_AUX). On the other hand, there was moderate agreement with the rest of the statements (S30_AUX, S31_AUX, S33_AUX and S34_AUX). Many respondents believed that accessibility was required for a good user experience and provided benefit for both abled and disabled people.

Table 10. Statements regarding the relationship between accessibility and UX

\begin{tabular}{|c|c|c|c|c|c|c|c|c|c|c|c|c|}
\hline \multirow[t]{2}{*}{ \# } & \multirow[t]{2}{*}{ Statements } & \multirow[t]{2}{*}{$\mathbf{N}$} & \multirow[t]{2}{*}{$\mathbf{M}$} & \multirow[t]{2}{*}{ sd } & \multicolumn{2}{|c|}{ Disagree } & \multicolumn{2}{|c|}{ Neutral } & \multicolumn{2}{|c|}{ Agree } & \multicolumn{2}{|c|}{ NA } \\
\hline & & & & & $\mathbf{n}$ & $\%$ & $\mathbf{n}$ & $\%$ & n & $\%$ & n & $\%$ \\
\hline S30_AUX & $\begin{array}{l}\text { Web accessibility is } \\
\text { necessary for good user } \\
\text { experience }\end{array}$ & 80 & 3.44 & 1.24 & 9 & 11.3 & 19 & 23.8 & 47 & 58.8 & 5 & 6.3 \\
\hline S31_AUX & $\begin{array}{l}\text { Web accessibility } \\
\text { problems are a subset of } \\
\text { user experience }\end{array}$ & 80 & 3.61 & 1.10 & 9 & 11.3 & 20 & 25 & 49 & 61.3 & 2 & 2.5 \\
\hline
\end{tabular}




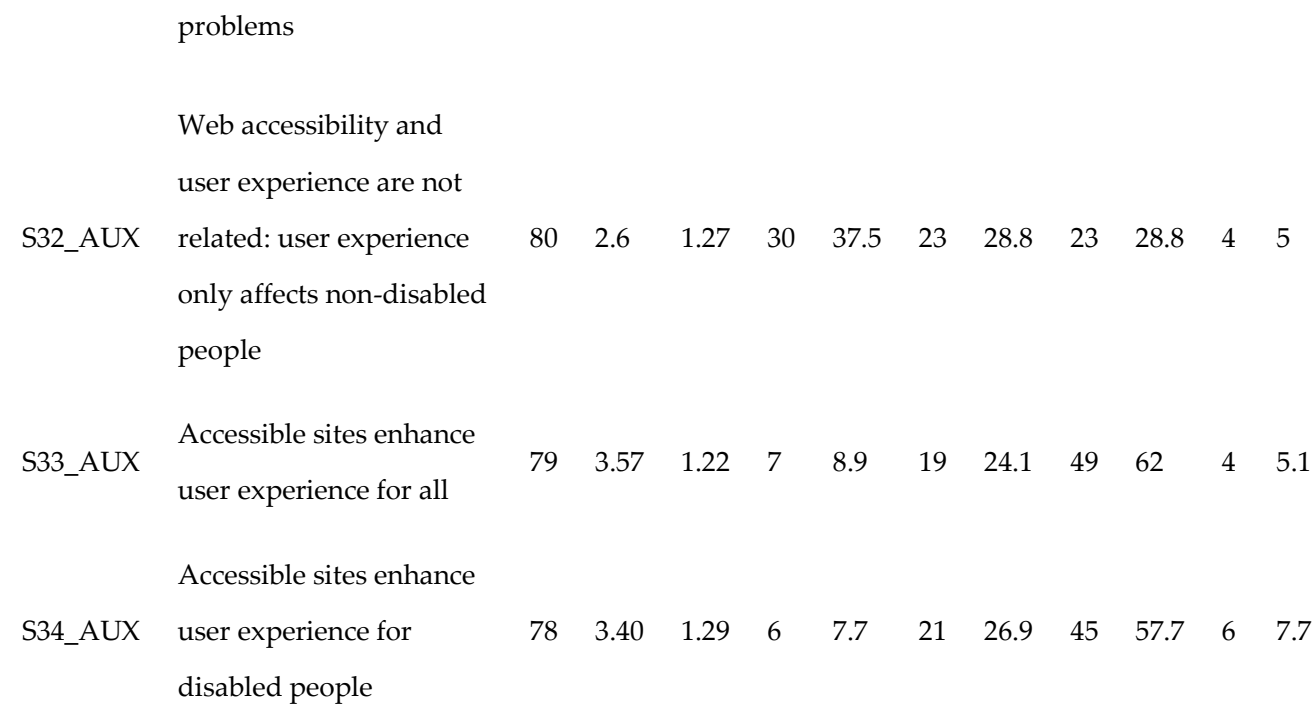

\section{Effect of factors on statements}

\section{- Effects of expertise}

Participants were considered in two groups as experts (E) and non-experts (NE) according to their expertise in accessibility practices. All the responses were statistically analyzed by twotailed unpaired t-test whether expertise had any effect on the scores of statements. Only the statements that showed significant difference due to expertise are given in Table 11.

Table 11. Effects of expertise (Expert (E) vs Non-Expert (NE)) on the score of the statements

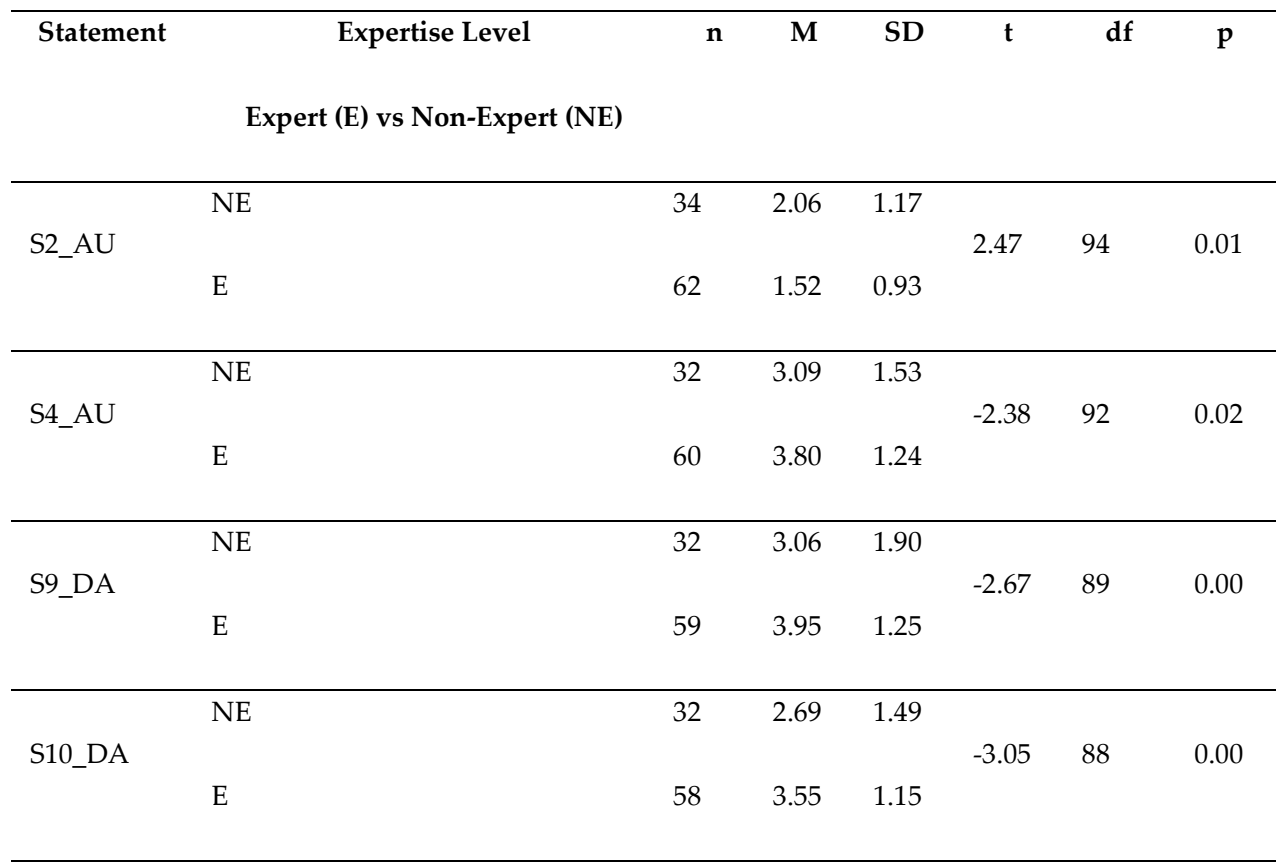




\begin{tabular}{|c|c|c|c|c|c|c|c|}
\hline \multirow{3}{*}{ S15_AD } & NE & 31 & 2.10 & 1.16 & \multirow{3}{*}{-4.16} & \multirow{3}{*}{85} & \multirow{3}{*}{0.00} \\
\hline & & & & & & & \\
\hline & E & 56 & 3.21 & 1.21 & & & \\
\hline \multirow{3}{*}{ S20_AE } & $\mathrm{NE}$ & 29 & 3.14 & 1.15 & \multirow{3}{*}{-2.38} & \multirow{3}{*}{82} & \multirow{3}{*}{0.02} \\
\hline & & & & & & & \\
\hline & E & 55 & 3.76 & 1.13 & & & \\
\hline \multirow{3}{*}{ S24_AE } & NE & 3.07 & 1.25 & 29 & \multirow{3}{*}{-2.35} & \multirow{3}{*}{82} & \multirow{3}{*}{0.02} \\
\hline & & & & & & & \\
\hline & E & 55 & 3.75 & 1.25 & & & \\
\hline
\end{tabular}

With statements regarding the relationship between accessibility and usability, expertise had an effect only on two of the statements of S2_AU and S4_AU as can be seen in Table 11. Regarding the statement S2_AU, non-experts agree more than experts that usability problems affect non-disabled people (S2_AU) $(\mathrm{t}(94)=2.47, \mathrm{p}<.001)$ while experts agree more than non-experts that accessible sites are more usable for all (S4_AU) $(\mathrm{t}(92)=2.38, \mathrm{p}<.001)$. In addition, regarding the statements whether accessibility was related with only disabled or all people, expertise again had a significant effect on two of the statements. These were S9_DA (Web accessibility problems affect all types of people regardless of their situational or physical limitations) $(\mathrm{t}(89)=2.67, \mathrm{p}<.000))$, and S10_DA (Web accessibility problems affect all types of people regardless of their situational or physical limitations) $(\mathrm{t}(88)=3.05, \mathrm{p}<$ .001)). These results show that experts agree more with statements stressing accessibility should be enabled for all people rather than it is being a concept for people who have a disability.

Regarding whether accessibility is driven by legislation or business revenue, there were two statements. It was revealed that expertise had a significant effect on only the statement S15_AD (Web accessibility is best viewed in terms of business revenue) $(\mathrm{t}(85)=4.16, \mathrm{p}<$ $.000))$.

Regarding the statements about the accessibility evaluation methods, expertise had a significant effect on two of the statements. These were S20_AE (Accessibility is personal experience and accessibility evaluation should take this into account $)(t(82)=2.38, p<.002))$ 
and S24_AE (To assess accessibility of a web page you need to be trained in WCAG) $(\mathrm{t}(82)=$ $2.35, \mathrm{p}<.002))$.

On the other hand, the results showed that expertise did not have any significant effect on any of the statements from other categories regarding page structure, the need of a standard definition for website accessibility and the relationship between accessibility and UX.

\section{- Effects of technical background}

Respondents were grouped according to their technical background as technical $(\mathrm{T})$ and nontechnical (NT). Background of respondents had significant effects on only two of the statements as can be seen in Table 12. These two statements were S18_AE (Compared to other methods web accessibility can be assessed more reliably and validly by running user tests), and S22_AE (Web accessibility of a page can be well assessed in less than five minutes) and these were from assessment methods category. Non-technical respondents valued on user tests more than technical respondents $(\mathrm{t}(85)=-2.31, \mathrm{p}<.02)$ ) and they also . Contrariwise, technical background did not have any significant effect on any of the statements in other categories regarding the relationship between usability and accessibility, whether accessibility was related with only disabled or all, page structure, the need of a standard definition and accessibility drivers.

Table 12. Effects of technical background (Technical (T) vs Non-Technical (NT)) on the score of the statements

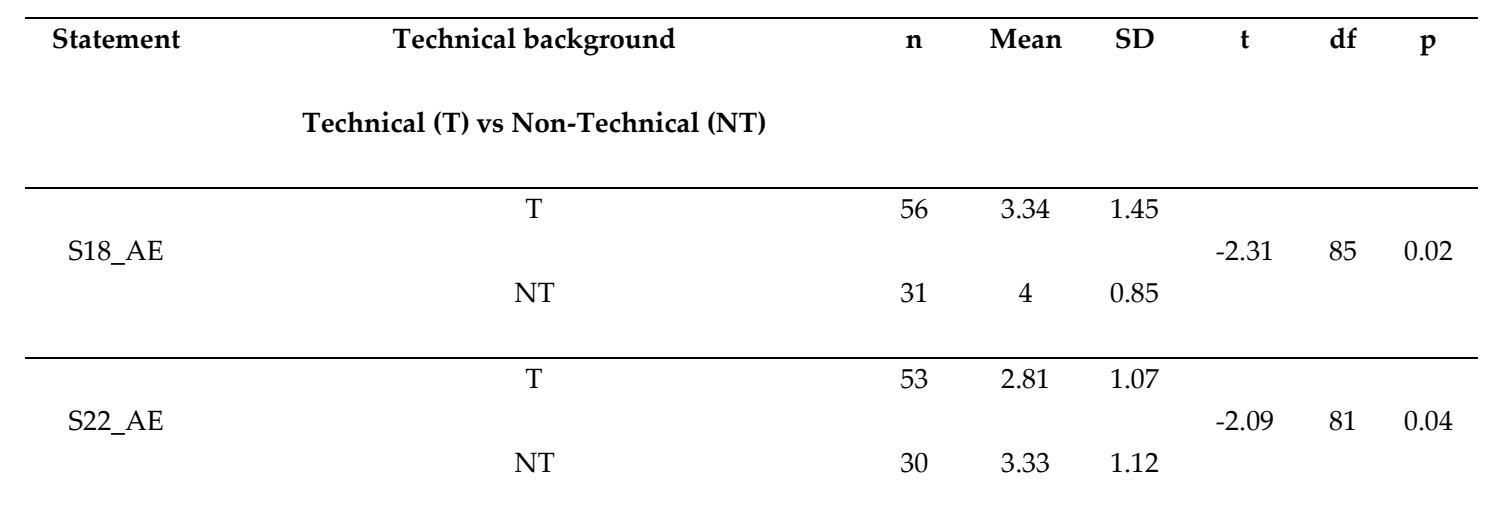

\section{- Effects of work domain}


Respondents' work domains was divided into two groups as governmental $(G)$ and private (P) based on their declared work sector. Respondents from governmental organizations significantly disagreed more to statements regarding the relationship of accessibility and usability as in Table 13. These were statements S1_AU (Web accessibility and usability problems are not related) $(\mathrm{t}(94)=-4.45, \mathrm{p}<.00))$ and S2_AU (Usability problems only affect non-disabled people) $(\mathrm{t}(94)=-2.84, \mathrm{p}<.01))$. On the other hand they significantly agreed more to S3_AU (Web accessibility problems are a subset of usability problems) $(\mathfrak{t}(90)=-2.47$, $\mathrm{p}<.01))$

In addition, respondents from governmental organizations also agreed more to statement S8_DA (Web accessibility problems only affect disabled people) $(\mathrm{t}(89)=-2.32, \mathrm{p}<.02)$ ). Regarding with the accessibility evaluation statements, work domain only had an effect on statement S21_AE (Web accessibility can be assessed by only inspecting the underlying source code of a page) $(\mathrm{t}(81)=-1.98, \mathrm{p}<.05)$ ). Finally statement S32_AUX (Web accessibility and user experience were not related: user experience only affects non-disabled people) had been affected by work domain of respondents $(t(78)=-2.91, p<.00)$ ). In contrast, work domain did not have any significant effect on other statements from the categories of accessibility drivers, page structure, and the need of a standard definition for web accessibility.

Table 13. Effects of work domain (Governmental (G) vs Private $(P)$ ) on the score of the statements

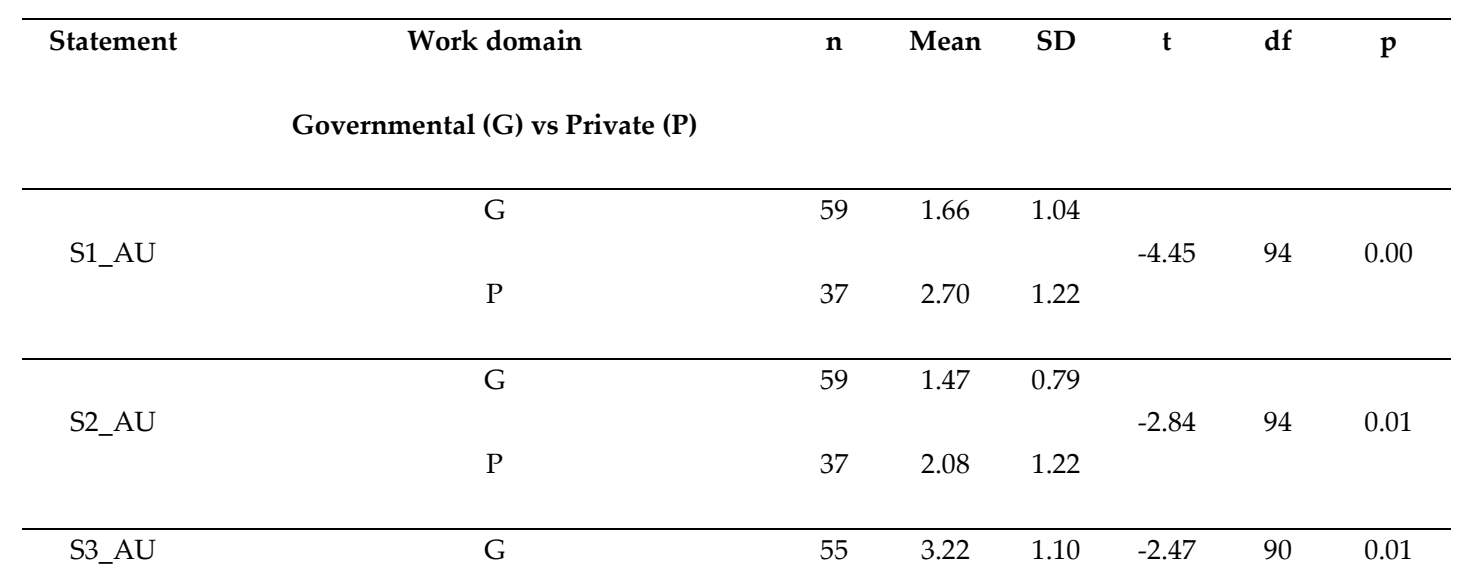




\begin{tabular}{|c|c|c|c|c|c|c|c|}
\hline & $\mathrm{P}$ & 37 & 3.76 & 0.89 & & & \\
\hline \multirow{3}{*}{ S8_DA } & $\mathrm{G}$ & 54 & 2.93 & 1.37 & \multirow{3}{*}{2.32} & \multirow{3}{*}{89} & \multirow{3}{*}{0.02} \\
\hline & & & & & & & \\
\hline & $\mathrm{P}$ & 37 & 2.27 & 1.23 & & & \\
\hline \multirow{3}{*}{ S21_AE } & $G$ & 49 & 3.02 & 1.28 & \multirow{3}{*}{1.98} & \multirow{3}{*}{81} & \multirow{3}{*}{0.05} \\
\hline & & & & & & & \\
\hline & $\mathrm{P}$ & 34 & 2.50 & 0.99 & & & \\
\hline \multirow{3}{*}{ S32_AUX } & G & 45 & 2.91 & 1.27 & \multirow{3}{*}{2.91} & \multirow{3}{*}{78} & \multirow{3}{*}{0.00} \\
\hline & & & & & & & \\
\hline & P & 35 & 2.11 & 1.13 & & & \\
\hline
\end{tabular}

\section{- Effects of specialization}

Respondents' current specializations were categorized as user-oriented (Uo) and non-user oriented (NUo) based on whether these roles dealt with users' needs. When the results were analyzed it was revealed that specialization had a significant effect on only two of the statements. These were S9_DA (Web accessibility problems affect all types of people regardless of their situational or physical limitations) $(\mathrm{t}(89)=-2.13, \mathrm{p}<.03))$ and S27_DC (Web accessibility occurs in and is dependent on the context in which the web page is experienced) $(\mathrm{t}(81)=-3.35, \mathrm{p}<.00))$. User-oriented specializations significantly agreed more that accessibility problems affected all people while non-user oriented specializations significantly agreed more that web accessibility was contextual as seen in Table 14 .

Table 1. Effects of specialization (User-oriented (Uo) vs Non-User-oriented (NUo)) on the score of the statements

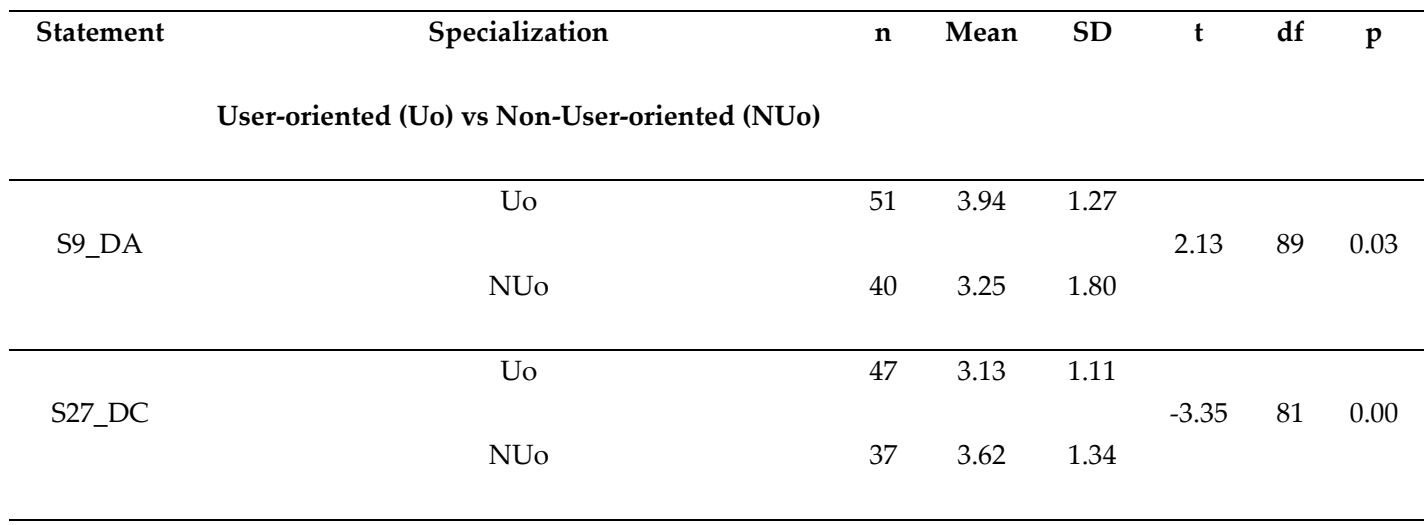




\section{CONCLUSION}

Web accessibility is a relevant social and technological issue. Although there were various researchers regarding the web accessibility awareness among the software professionals, there were few studies regarding their perceptions of website accessibility. Since their perceptions also effects their implementations of enabling web site accessibility (Yesilada et al., 2015), an explanatory study was conducted with Turkish software professionals to gather their perceptions regarding the relationship between accessibility, user experience and usability concepts as well as professionals' perspectives on related issues such as the need of a standard accessibility definition, accessibility evaluation methods, and accessibility drivers.

A web-based questionnaire was implemented with 108 participants from academy, industry and government. The results showed that when software professionals were given various definitions from the literature for web accessibility, most of them preferred the ones that were more inclusive (D1, D2 and D3 in Table 3). In addition, most of them disagreed that usability problems of web sites and web accessibility problems only affects people with disabilities. In addition, many of the respondents thought that web accessibility problems are a subset of usability problems and these two concepts are closely related. From the UX perspective, they agreed that web accessibility problems are a subset of UX problems, too and web accessibility is a necessary condition to enhance UX for all. Moreover, many of them agreed that the user-centered practices should be applied to enable the website accessibility. Therefore it can be said that software professionals think that accessibility, usability and UX are all intertwined concepts. Most of the participants also required for a standard definition for website accessibility. They also believe that legislation could be the main motivation for ensuring web accessibility than business revenue in organizations.

According to t-test results, expertise level and work sector of software professionals had effects on more statements while technical background of the professionals and their specialization had effects on a very few statements. While expertise level increases software professionals thought that accessible sites are more usable for all people while nonexperienced professionals thought that these concepts are related with only non-disabled 
people. Thus it can be said that the experienced professionals accepts web accessibility as a more inclusive concept. In addition regarding the accessibility evaluation methods experts see accessibility as an individual experience and they emphasized the use of standards such as WCAG for the evaluation. Similarly work sector of the professionals (governmental or private), had effects on more statements regarding the relationship of accessibility and usability, the scope of website accessibility, accessibility evaluation, and the relationship of accessibility and UX. Respondents from governmental organizations are agreed more that web accessibility and usability problems are related and problems are related with all people, like experienced professionals. They value more technical evaluation methods depending on the source code of the websites. Finally, they believed that UX and web accessibility is interrelated, too. These views of software professionals from governmental organizations might depend on the declaration of ensuring accessibility of public websites by the Ministry of Family and Social Policies (2019).

The findings from this study provides the snapshot of the Turkish situation regarding website accessibility perceptions among the software professionals. However, since the results have overlapping points with Yesilada et al.'s adopted study (Yesilada et al., 2015). As a conclusion, the study has a practical implications for researchers or policy makers at government or educational institutions in Turkey and in other countries. Some important implications can be listed as providing accessibility trainings including WCAG, in degree programs or in-service trainings at organizations. Accessibility laws or regulations should be put into effect to improve accessibility issues and to enable awareness for all developers. Thus it will be possible to provide universal design accessible to everyone.

The study has several limitations. First to be mentioned is that there are threats to its external validity which is related with the generalizations of the results. The results cannot be generalized since the professionals participating were all from organizations in Turkey. In addition the number of participants can be considered low. Gathering data from more participants as well as participants from different countries as a future work would extend the scope the results of the study. In addition, future studies should consider using SEM or expand on data analysis using MLR as well. 


\section{Notes}

* Questionnaire for the perceptions of software professionals regarding website accessibility

\section{https://drive.google.com/open?id=1snmlrROAsTLPUO1KVanrXhdD3AQ4XSle}

\section{REFERENCES}

Aizpurua, A., Harper, S., \& Vigo, M. (2016). Exploring the relationship between web accessibility and user experience. International Journal of Human-Computer Studies, 91, 13-23. https://doi.org/10.1016/j.ijhcs.2016.03.008

Antonelli, H. L., Rodrigues, S. S., Watanabe, W. M., \& de Mattos Fortes, R. P. (2018). A survey on accessibility awareness of Brazilian web developers. Proceedings of the 8th International Conference on Software Development and Technologies for Enhancing Accessibility and Fighting Info-Exclusion, 71-79. https://doi.org/10.1145/3218585.3218598

Arch, A. (2009). Web Accessibility for Older Users: Successes and Opportunities (Keynote). Proceedings of the 2009 International Cross-Disciplinary Conference on Web Accessibililty (W4A), 1-6. https://doi.org/10.1145/1535654.1535655

Black, J. A., \& Champion, D. J. (1976). „Methods and Issues in Social Research,“ John Wiley \& Sons.

Cao, S., \& Loiacono, E. (2018). Perceptions of Web Accessibility Guidelines by Student Website and App Developers. 5 .

Cojocar, G. S., \& Guran, A. M. (2013). Evaluation of Romanian Academic Websites Accessibility. A Case Study. Studia Universitatis Babes-Bolyai, Informatica, 58(4).

Enabled Group. (2005). ENABLED | Analysis. http://www.enabledweb.org/public_results/survey_results/analysis.html

TTB, (2009) Engellilerin Haklarına İlişkin Sözleşme. https://www.ttb.org.tr/mevzuat/index.php?option=com_content\&view=article\&id=686:engellerhaklarina-k-slee\&Itemid=36

The Ministry of Family and Social Policies, (2019). Erişilebilirlik - Aile, Çalışma ve Sosyal Hizmetler Bakanlığ1 Engelli ve Yaşlı Hizmetleri Genel Müdürlüğü. (2019, March 18). https://eyh.aile.gov.tr/erisilebilirlik

Ferreira, S. B. L., dos Santos, R. C., \& da Silveira, D. S. (2007). Panorama of Brazilian web accessibility. Proceedings of the XXXI ANPAD Meeting-EnANPAD, Page 17p.

Freire, A. P., Russo, C. M., \& Fortes, R. P. M. (2008). A survey on the accessibility awareness of people involved in web development projects in Brazil. Proceedings of the 2008 International Cross-Disciplinary Conference on Web Accessibility (W4A), 87-96. https://doi.org/10.1145/1368044.1368064

Hassenzahl, M. (2018). The thing and I: understanding the relationship between user and product. In Funology 2 (pp. 301-313). Springer, Cham.

Henry, S. L. (2007). Just Ask: Integrating Accessibility Throughout Design. Lulu.com.

Inal, Y., Rızvanoğlu, K., \& Yesilada, Y. (2019). Web accessibility in Turkey: Awareness, understanding and practices of user experience professionals. Universal Access in the Information Society, 18(2), 387-398. https://doi.org/10.1007/s10209-017-0603-3

Insfran, E., \& Fernandez, A. (2008). A Systematic Review of Usability Evaluation in Web Development. In S. Hartmann, X. Zhou, \& M. Kirchberg (Eds.), Web Information Systems Engineering - WISE 2008 Workshops (pp. 81-91). Springer. https://doi.org/10.1007/978-3-540-85200-1_10 
Ismail, A., \& Kuppusamy, K. S. (2018). Accessibility of Indian universities' homepages: An exploratory study. Journal of King Saud University - Computer and Information Sciences, 30(2), 268-278. https://doi.org/10.1016/j.jksuci.2016.06.006

ISO 9241-20:2008. (2008). Ergonomics of Human-System Interaction -Part 20: Accessibility Guidelines for Information/Communication Technology (ICT) Equipment and Services. https://www.iso.org/obp/ui/\#iso:std:iso:9241:-20:ed-1:v1:en

ISO. (2019). ISO 9241-210:2019 Ergonomics of human-system interaction - Part 210: Human-centred design for interactive systems. https://www.iso.org/standard/77520.html

KAMIS. (2019). Erişilebilirlik Nedir? https://kamis.gov.tr/erisebilirlik-nedir/

Kurt, S. (2017). Accessibility of Turkish university Web sites. Universal Access in the Information Society, 16(2), 505-515. https://doi.org/10.1007/s10209-016-0468-x

Laux, L. (1998). Designing Web pages and applications for people with disabilities. Human Factors and Web Development, 87-95.

Lazar, J., Dudley-Sponaugle, A., \& Greenidge, K.-D. (2004). Improving web accessibility: A study of webmaster perceptions. Computers in Human Behavior, 20(2), 269-288. https://doi.org/10.1016/j.chb.2003.10.018

Little, R. J. (1988). A test of missing completely at random for multivariate data with missing values. Journal of the American statistical Association, 83(404), 1198-1202.

Lopes, R., Van Isacker, K., \& Carriço, L. (2010). Redefining Assumptions: Accessibility and Its Stakeholders. In K. Miesenberger, J. Klaus, W. Zagler, \& A. Karshmer (Eds.), Computers Helping People with Special Needs (pp. 561-568). Springer. https://doi.org/10.1007/978-3-642-14097-6_90

Menzi-Çetin, N., Alemdağ, E., Tüzün, H., \& Yıldız, M. (2017). Evaluation of a university website's usability for visually impaired students. Universal Access in the Information Society, 16(1), 151-160. https://doi.org/10.1007/s10209-015-0430-3

Nielsen, J. (1994). Usability Engineering. Morgan Kaufmann.

Nielsen, J. (1999). Designing Web Usability: The Practice of Simplicity. New Riders Publishing.

Offutt, J. (2002). Quality attributes of Web software applications. IEEE Software, 19(2), 25-32. https://doi.org/10.1109/52.991329

Oppenheim, A. N. (2000). Questionnaire design, interviewing and attitude measurement. Bloomsbury Publishing.

Paddison, C., \& Englefield, P. (2004). Applying heuristics to accessibility inspections. Interacting with Computers, 16(3), 507-521. https://doi.org/10.1016/j.intcom.2004.04.007

Petrie, H., \& Kheir, O. (2007). The relationship between accessibility and usability of websites. Proceedings of the SIGCHI Conference on Human Factors in Computing Systems, 397-406. https://doi.org/10.1145/1240624.1240688

Putnam, C., Wozniak, K., Zefeldt, M. J., Cheng, J., Caputo, M., \& Duffield, C. (2012). How do professionals who create computing technologies consider accessibility? Proceedings of the 14th International ACM SIGACCESS Conference on Computers and Accessibility, 87-94. https://doi.org/10.1145/2384916.2384932

Rosson, M. B., Ballin, J. F., Rode, J., \& Toward, B. (2005). “Designing for the Web” Revisited: A Survey of Informal and Experienced Web Developers. In D. Lowe \& M. Gaedke (Eds.), Web Engineering (pp. 522-532). Springer. https://doi.org/10.1007/11531371_66

Section 508. (2018). Section508.gov I GSA Government-wide Section 508 Accessibility Program. https://www.section508.gov/

Shneiderman, B. (2000). Universal Usability. Commun. ACM, 43(5), 84-91. https://doi.org/10.1145/332833.332843

Tangarife, T. M., \& Mont'alvao, C. (2006). What the brazilian developers know about web accessibility and digital inclusion. Proceedings of the 6 USIHC-6 International Congress on Ergonomics, Usability, Interface Design and Human-Computer Interaction, Page 6p. 
Thatcher, J., Burks, M., Heilmann, C., Henry, S. L., Kirkpatrick, A., Lauke, P. H., Lawson, B., Regan, B., Rutter, R., Urban, M., \& Waddell, C. (2006). Web Accessibility: Web Standards and Regulatory Compliance. Apress. https://jimthatcher.com/book2/

Thompson, T., Burgstahler, S., \& Comden, D. (2003). Research on Web Accessibility in Higher Education. 16.

Trewin, S., Cragun, B., Swart, C., Brezin, J., \& Richards, J. (2010). Accessibility challenges and tool features: An IBM Web developer perspective. Proceedings of the 2010 International Cross Disciplinary Conference on Web Accessibility (W4A), 1-10. https://doi.org/10.1145/1805986.1806029

TurkStat, “Population and Housing Census 2011. (2019, March 18). https://eyh.aile.gov.tr/nufus-ve-konutarastirmasi-2011

Vollenwyder, B., Iten, G. H., Brühlmann, F., Opwis, K., \& Mekler, E. D. (2019). Salient beliefs influencing the intention to consider Web Accessibility. Computers in Human Behavior, 92, 352-360. https://doi.org/10.1016/j.chb.2018.11.016

W3C. (1999). Web Content Accessibility Guidelines (WCAG) 1.0. https://www.w3.org/TR/WAI-WEBCONTENTTECHS/

W3C. (2008). Web Content Accessibility Guidelines (WCAG) 2.0. https://www.w3.org/TR/WCAG20/

W3C_WAI. (2019). Introduction to Web Accessibility. Web Accessibility Initiative (WAI). https://www.w3.org/WAI/fundamentals/accessibility-intro/

Waddell, C., Regan, B., Henry, S. L., Burks, M. R., Thatcher, J., Urban, M. D., \& Bohman, P. (2003). Constructing accessible web sites. Apress.

WAI. (2018). WAI. Web Accessibility Initiative (WAI). https://www.w3.org/WAI/

Who. (2019, March 18). WHO I World report on disability. http://www.who.int/disabilities/world_report/2011/report/en/

Yerlikaya, Z., \& Onay Durdu, P. (2018). Yazılım Profesyonellerinin Web Erişilebilirliği Farkındalıkları Üzerine Bir Araştırma: Türkiye'deki Durum. 12th International Computer \& Instructional Technologies Symposium.

Yesilada, Y., Chuter, A., \& Henry, S. L. (2013). Shared web experiences: Barriers common to mobile device users and people with disabilities. W3C Web Accessibility Initiative Http://Www. W3. Org/WAI.

Yesilada, Yeliz, Brajnik, G., Vigo, M., \& Harper, S. (2015). Exploring perceptions of web accessibility: A survey approach. Behaviour \& Information Technology, 34(2), 119-134.

Yesilada, Yeliz, Brajnik, G., Vigo, M., \& Harper, S. (2012). Understanding web accessibility and its drivers. Proceedings of the International Cross-Disciplinary Conference on Web Accessibility, 19.

Zaphiris, P., \& Ellis, R. D. (2001). Website usability and content accessibility of the top USA universities. https://ktisis.cut.ac.cy/handle/10488/5263 


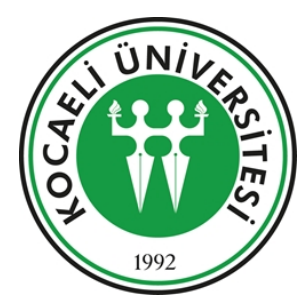

\title{
T.C.
}

\section{KOCAELİ ÜNIVERSITESI \\ Fen ve Mühendislik Bilimleri Etik Kurulu}

Say1 : 10017888-199/

Konu : Etik Kurul Onay hk.

Sayın Dr. Ögr. Üyesi Pınar ONAY DURDU

İlgi : 99/04/2019 tarihli, 29152 sayılı ve "Etik Kurul Onayı hk" konulu yazı

Fen ve Mühendislik Bilimleri Etik Kurulunun 15/04/2019 tarih ve 2019/06 nolu toplantısında alınan 2 sıra sayılı kararı aşağıda sunulmuştur.

Bilgilerinize rica ederim.

\section{Prof.Dr. Alpaslan FIĞLALI Kurul Başkanı}

\begin{abstract}
Karar No 2: Mühendislik Fakültesi Bilgisayar Mühendisliği bölümü öğretim üyesi Dr.Öğr.Üyesi Pınar ONAY DURDU'nun 09/04/2019 tarih ve 29152 sayılı başvurusu görüşüldü. Web sitesi geliştirmenin herhangi bir aşamasında görev alan yazılım geliştirme alanındaki uzmanların web sitesi erişilebilirliği konusundaki farkındalıkları ve uyguladıkları güncel pratiklere yönelik olarak mevcut durumun ortaya çıkarılmasını amaçlayan "Web Erişilebilirliği: Yazılım Geliştiricilerin Perspektifi" konulu araştırma çalışması için kullanacağı anket kapsamında kişisel bilgi toplamaya yönelik bir soru bulunmadığından, verilerin anonim olarak toplanması hedeflendiğinden ve gönüllü katılımcıların onayları alındığından; bilimsel araştırma ve yayın etiği açısından bir sakınca olmadığına oy birliği ile karar verildi.
\end{abstract}

